\title{
LOS DESCUIDOS DE CERVANTES Y LA PRIMERA TRANSFORMACIÓN DE DULCINEA
}

Los descuidos de Cervantes han sido un argumento tradicionalmente incómodo para la crítica del Quijote y sobre manera para la del siglo XX. La idea básica de casi todas las mayores aportaciones del cervantismo contemporáneo ha sido la de la conciencia de Cervantes como escritor y su prematuro dominio de los más recónditos secretos del arte novelístico. Es algo generalmente aceptado que la primera formulación de esta idea se encuentra en la doble refutación del tópico del Cervantes ingenio lego - tan difundido entre los estudiosos de otras épocas- realizada a principios del corriente siglo por Ortega, primero, y Castro, después ${ }^{~}$. El hecho de que la crítica le reconociera al autor del Quijote su intención artística, si por un lado aseguró una interpretación del texto más en consonancia con las coordenadas estéticas e ideológicas del Siglo de Oro, libre de los excesos esotéricos de la centuria decimonónica, por el otro, al colocarse en la tradición hermenéutica transcendental propia del romanticismo que veía en el Quijote una suerte de precipitado de los valores patrios, o más generalmente humanos, y aun cuando se esforzara por desbrozar esa lectura tradicional de aquel otro tipo de exceso que consistía en situar en el centro de la interpretación al personaje en menoscabo de la labor del escritor, no consiguió evitar lo que a mi modo de ver constituía el mayor peligro y la mayor tentación del impulso revalorizador romántico, o sea, una suerte de idealización del autor y su obra que, si a principios del XIX se hacía necesario para sacar el gran libro del olvido de los tiempos, una centuria

J. ORTEga y Gasset, Meditaciones del Quijote, ed. de J. Marías. Madrid, Cátedra, 1984 [1." ed. 1914] y A. CASTRO, El pensamiento de Cervantes. Madrid, Hernando, 1925. 
más tarde acabó por cerrar el paso a cualquier tipo de consideración que pusiera en tela de juicio las excelencias de la prosa cervantina. Así fue como los descuidos de Cervantes y todo aquello que recordara las viejas muletillas sobre la "feliz improvisación" ?, o la "afortunada inspiración del autor", o las extremadas comparaciones entre Colón y Cervantes - dos grandes hombres que murieron sin saber el alcance real de sus empresas 3-, etc., fueron sistemáticamente excluidos, a priori, de casi todos los análisis de la obra * Hicieron falta siglos de erudición, se diría que pensaron los cervantistas, para ahuyentar el fantasma de la inconsciencia de Cervantes, como para que ahora nadie corra el riesgo de reconvocarlo, simplemente por satisfacer lo que podría no ser más que un prurito de estudioso. Las consecuencias de esta postura, hasta cierto punto intransigente, han sido que, en la época que ha visto el afianzamiento de la crítica literaria como ciencia, con el consiguiente triunfo de los enfoques formalistas y objetivos, no contamos aún con un estudio de conjunto de la coherencia textual en el Quijote, que afronte el argumento desde una perspectiva imparcial, sin condicionamientos ni apriorismos que establezcan de antemano la conclusión a la que el estudio ha de llegar. Por todo esto tal vez nos resulte excesivo afirmar que, si bien la crítica viene ponderando desde hace mucho tiempo los logros estéticos de Cervantes y sus geniales intuiciones, precursoras de un género destinado a gozar del favor del público lector, ninguno de esos juicios y consideraciones podrá seguir siendo tenido en cuenta mientras no sea confrontado con el arduo problema de las incoherencias narrativas de nuestro autor.

2 Tan difíciles de arraigar que se puede hallar incluso repetidas en un autor poco sospechoso de menoscabar la conciencia artística de Cervantes como $R$. MENÉnDEZ PIDAL, "Un aspecto en la elaboración del Quijote» (1920), en España y su historia, vol. II. Madrid, Minotauro, 1957, pp. 179-211 [p. 193].

3 Así lo expresó F. Rodríguez Marín en el tomo IV (p. 303) de su edición, levantando resquemores en la sensibilidad ideológica de CASTRO (El pensamiento de Cervantes, cit., p. 15). La misma comparación la encontramos modernamente en la obra de C. Fuentes, Cervantes o la crítica de la lectura. México, Joaquín Mortiz, 1976, p. 13.

4 Entre las pocas excepciones caben mencionar los trabajos de G. StaGG («Sobre el plan primitivo del Quijotew, Actas del primer congreso internacional de hispanistas. Oxford, Dolphin book, 1964, pp. 463-471; y "Cervantes revisa su novela (Don Quijote, I Parte)», Anales de la Universidad de Chile, 140, 1966, pp. 5-33, en los que partiendo de los descuidos estudia las posibles remodelaciones del texto de Cervantes. G. B. Palacín (En torno al Quijote. Madrid, Ediciones Leira, 1965, pp. 188-211) considera los descuidos parte de la técnica cervantina. También trata el argumento, aunque sin profundizar en él y limitándose a enumerar y comentar algunos casos de descuido E. MORENO BÁEz, Reflexiones sobre el Quijote. Madrid, Prensa Española, 1968, pp. 62-5. A. Rosenblat, la lengua del Quijote. Madrid, Gredos, 1971, pp. 243-345. R. M. FLORES, "Cervantes at work: the writing of Don Quixote Part I", Journal of Hispanic Philology, III, 1979, pp. 135-160. V. GAOS en el tercer volumen de su edición del Quijote (Madrid, Gredos, 1987) dedica un apéndice a "Los errores de Cervantes», pp. 201-234, y en muchas de sus notas al texto sale al paso de las correcciones a Cervantes. 
Pero para que esto pueda suceder es necesario que esa misma crítica que supo reaccionar contra los excesos de quienes defendían la inconsciencia cervantina, sepa ahora también liberarse de unos prejuicios normativos que la emparentan directamente con aquella otra denostada rama de la familia cervantista. Es necesario, en pocas palabras, que deje de experimentar esa especie de vergüenza ajena ante las propiedades lingüísticas y estructurales de un escritor que no escribía según los cánones estéticos con los que inmisericordemente se le juzga, y de buscar por todos los medios una justificación plausible para su admirado, porque todo ello no es más, al fin y al cabo, que la cruz de la misma moneda con la que pagaron los defensores de la tesis de la feliz casualidad los desvelos del arte cervantino, la aplicación partidista del mismo criterio estético. Acaso una alternativa posible a la perenne elusión del problema' sea la de empezar a interpretar las incongruencias narrativas en el Quijote desde un punto de vista que me atrevería a definir como filológico, o sea verlos como indicios de las diversas revisiones del texto por parte del autor, y por tanto como otras posibles pruebas de las diferentes fases de elaboración textual ${ }^{6}$.

En este breve ensayo me detendré sobre todo en las varias imágenes que caballero y escudero nos han legado de Dulcinea del Toboso, intentando percibirlas sobre el transfondo de las incongruencias narrativas de Cervantes. Como tal vez el lector ya haya adivinado, estudiaré con especial atención los episodios de Sierra Morena, por ser allí donde don Quijote y Sancho confrontan por primera vez sus respectivos puntos de vista sobre Dulcinea. La confrontación es importante, porque, como se sabe, de ella nacerá una de las líneas fundamentales del argumento de la II Parte (es decir, la transformación de la alta dama en vulgar aldeana '), y porque la diversidad de puntos de vista que alberga ha estimulado a los estudiosos del Quijote: en ella algunos críticos han creído vislumbrar una autoconciencia del caballero y una evolución de su personalidad sobre la que después han construido toda una interpretación de la obra ${ }^{8}$.

S Valga un ejemplo por todos: así ventila la cuestión de los descuidos E. C. RILEY (Teoria de la novela en Cervantes. Madrid, Taurus, 1962, p. 52 [1.a ed. inglesa 1962]): "la leyenda que considera a Cervantes como un genio sonriente y descuidado ha sido sustituida, en general, por una mejor apreciación de su capacidad reflexiva y crítican.

${ }_{6}$ Que es el principio sobre el que ya se fundan los trabajos de Stagg y Flores anteriormente citados.

7 Cfr. J. Rodriguez-Luis, "Dulcinea a través de los dos Quijotes", Nueva Revista de Filología Hispánica, XVIII, 1965-1966, pp. 378-416.

8 Me estoy refiriendo a las obras de M. VAN DOREN, La profesión de Don Quijote. México, Fondo de Cultura Económica, 1973 (1.: ed. inglesa 1958), y G. TORRENTE BALLESTER, El Quijote como juego. Madrid, Guadarrama, 1975. 


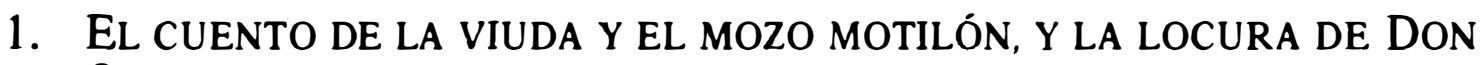
QUIJOTE

1.1. De camino de la venta de Palomeque, después de que el cura y Dorotea consigan que don Quijote abandone los abruptos parajes de la Sierra, amo y escudero se apartan de la comitiva a tratar de la mentida embajada a Dulcinea [I,31] "; don Quijote entonces somete a Sancho a un verdadero interrogarorio, y éste ha de hacer un notable esfuerzo de fantasía para que su amo no descubra lo que al lector le será revelado por medio del narrador:

"Puesto que [aunque] él sabía que Dulcinea era una labradora del Toboso, no la habia visto en toda su vida" $(2,429)$.

Sancho se deja ir a un desahogo que contradice de lleno unas palabras suyas de algunos capítulos atrás en las que declaraba que conocía perfectamente a la hija de Lorenzo Corchuelo [I,25,2,269]. Esta contradicción sorprende, y no poco, al lector por las circunstancias en que se produce, cuando ya Sancho se había liberado del acoso inquisitivo de don Quijote, lo que la hace aún más evidente e innecesaria.

Pero no es Sancho el único que desmiente sus propias manifestaciones; en este mismo episodio también lo hará don Quijote: unos capítulos antes había solventado la cuestión de la autenticidad de una carta que debía ser transcrita por otro, arguyendo que "a lo que yo me sé acordar, Dulcinea no sabe escribir ni leer" $[1,25,2,267]$; en la misma página, ya con un atisbo de contradicción, reconoce que nunca ha hablado con Dulcinea, y podría ser que de las «cuatro veces [que la he visto] no hubiese ella echado de ver la una que la miraban; inútil, entonces, preguntarse cómo pudo llegar a percatarse de que no sabía leer. Pues bien, en I,31 la contradicción se hace patente en una pregunta de don Quijote a Sancho "¿qué hizo cuando leyó la carta?» [2,422]; tendrá que ser el propio Sancho el que le recuerde, ahora, que Dulcinea no conoce las primeras letras: "la carta [...] no la leyó, porque dijo que no sabía leer ni escribirn.

Los dos personajes contradicen en su diálogo de I,31 sus palabras de I,25, y siempre en relación con Dulcinea; sobre ella conocen determinados detalles en I,25 que luego niegan en I,31; con lo que dos episodios que deberían ser complementarios, por cuanto el uno narra el resultado de una acción planeada en el otro, en ciertos aspectos resultan ser no sólo contrarios sino incluso con-

9 He manejado la edición del Quijote de F. Rodríguez Marín. Madrid, Atlas, 1947-9, 10 tomos. A partir de ahora, para mayor comodidad, me referiré a esta edición utilizando corchetes en los que irán consignados la parte del Quijote en números romanos y en números arábigos, por este orden, el tomo y la página. 
tradictorios. Para mejor focalizar dichos aspectos convendrá que nos detengamos en la comparación de los dos episodios.

Don Quijote comunica a Sancho la delicada misión que le piensa encomendar; le enviará al Toboso con una carta de amores para Dulcinea ${ }^{10}$, mientras él lo espera en Sierra Morena haciendo penitencia al estilo de Amadís en Peña Pobre. En la conversación que sigue don Quijote encarece el recato de sus amores con Dulcinea, obligado por el apartamiento en que la tienen sus padres, y termina por informar a Sancho de la identidad real de su amada. Sancho se lanza entonces a un desaforado elogio de su señora, pero, como se refiere exclusivamente a la campesina que él conoce y no a la alta princesa de su amo, el elogio se vuelve of ensa en la óptica del caballero. Don Quijote reacciona intentando salvar su imagen de Aldonza/Dulcinea, para lo que no se le ocurre nada mejor que contarle a Sancho cómo había nacido la alta dama de sus ensueños. Al hacerlo contradice el fondo y la forma de sus anteriores discursos y la imagen de su amada que con tanto denuedo ha defendido por toda Mancha. Reconoce, en efecto, don Quijote que ha acomodado intencionalmente la figura de la rústica aldeana a los presupuestos de dama de caballero andante; y lo hace con una suerte de chascarrillo popular, narrado a modo de enxemplum - recurso retórico que rara vez usará después-, cargado de unas alusiones eróticas que nunca antes habíamos encontrado en sus palabras y nunca más volveremos a encontrar. Pero concedamos la palabra a don Quijote

"Ya te tengo dicho antes de agora muchas veces, Sancho - dijo don Quijote-, que eres muy grande hablador y que, aunque de ingenio boto, muchas veces despuntas de agudo; mas para que veas cuán necio eres tú y cuán discreto soy yo, quiero que me oyas un breve cuento. Has de saber que una viuda hermosa, moza, libre y rica, y sobre todo, desenfadada, se enamoró de un mozo motilón, rollizo y de buen tomo; alcanzólo a saber su mayor, y un día dijo a la buena viuda, por vía de fraternal reprehensión: "Maravillado estoy, señora, y no sin mucha causa, de que una mujer tan principal, tan hermosa y tan rica como vuestra merced se haya enamorado de un hombre $\tan$ soez, tan bajo y tan idiota como fulano". [...] Mas ella le respondió con mucho donaire y desenvoltura: "Vuestra merced, señor mío, está muy engañado, y piensa muy a lo antiguo si piensa que yo he escogido mal en fulano, por idiota que le parece; pues para lo que yo le quiero, tanta filosofía sabe, y más, que Aristóteles". Así que, Sancho, por lo que yo quiero a Dulcinea del Toboso, tanto vale como la más alta princesa de la tierra. [...] Y así, bástame a mí pensar y creer que la buena de Aldonza Lorenzo es hermosa y honesta, y en lo del linaje, importa poco; que no han de ir a hacer la información dél para darle algún hábito, y yo me hago cuenta que es la más alta princesa del mundo. [..] $Y$ para concluir con todo, yo imagino que todo lo que digo es así, sin que sobre ni falte nada, y píntola en mi imaginación como la deseo. [...] Y diga cada uno lo que quisiere; que si por esto fuere

10 De esta misiva se ocupa en términos muy elogiosos P. SALINAS, "La mejor carta de amores de la literatura españolaw, AA.VV., El "Quijote" de Cervantes, ed. de G. Halev, Madrid, Taurus, 1987, pp. 109-141. 
reprehendido de los ignorantes, no seré castigado de los rigurosos" $[\mathrm{I}, 25,2,272-6]$.

Aun a riesgo de ser tildados de ignorantes por don Quijote, habrá que reprehender en su discurso la falta de coherencia entre este desclasamiento de Dulcinea a simple aldeana y su idealización anterior, y entre el evidente regodeo en los aspectos materiales de la existencia ", más propio de un Sancho que de don Quijote, y su adhesión incondicional al código caballeresco.

Don Quijote separa netamente a Aldonza de Dulcinea, pero reconoce que entre ambas hay una sustancial identidad; existen distintamente, viene a decir, sólo porque pertenecen a mundos diferentes antes de que don Quijote intervenga y transforme el uno en el otro; ¿cómo? muy sencillo, le basta "con pensar y creer que la buena de Aldonza Lorenzo es hermosa y honesta" [I,25,2,275], para convertirla en Dulcinea, doncella a la que "en ser hermosa, ninguna le iguala; y en la buena fama, pocas le llegan" [276]. La voluntad de creer de don Quijote, supremo alquimista de la fantasía, es el alambique que destila el sublime ideal (Dulcinea) de la realidad grosera (Aldonza). En esta declaración no hay incoherencia alguna; ya sabíamos que la clave de los actos de don Quijote estaba en el intento platónico de restituir a las apariencias (Aldonza) sus esencias (Dulcinea). Lo incoherente es esa explícita complacencia con los resortes mágicos de su imaginación, que implica que don Quijote es consciente de la transformación que opera en Aldonza $\mathrm{y}$, por tanto, también de la que lleva a cabo con las demás personas y cosas, y que, por consiguiente, su decisión de hacerse caballero andante no es más que una representación, una farsa en la que nunca, ni por un momento, ha creído ${ }^{12}$. Toda esta claridad mixta a cinismo mal se aviene con las continuas disputas del promotor del ideal contra el Sancho materialista y con toda una serie de afirmaciones de don Quijote, como ésta que transcribo a continuación, levemente anterior al desmentido, en la que, aunque no se refiere a Dulcinea, se puede comprobar la solidez de su posición frente al fingimiento; propone Sancho a don Quijote un modo de no hacerse demasiado daño en sus excesos de loco enamorado:

"Ya que a vuestra merced le parece que son aquí necesarias calabazadas [...][seria yo de parecer que ] se contentase, pues todo es fingido y

1 Para un lector de tan fina sensibilidad como S. DE Madariaga, Guía del lector del Quijote. Buenos Aires, Editorial Sudamericana, 1947 [1.* ed. 1923-25], p. 139; el cuento de la viuda alegre "suena a falso por lo vulgar [...]. El idealista, halagando al realista, mide mal el desnivel y cae en el cinismon.

${ }_{12}$ Después de analizar ésta y otras escenas parecidas en las que don Quijote da buena muestra de su clarividencia. VAN DOREN (op. cit., p. 9 y passim) y TORRENTE BALLESTER (op. cit., p. 60 y passim) proponen la figura de un don Quijote actor, consciente de estar representando el papel de loco ante los demás. 
cosa contrahecha y de burla, se contentase, digo, con dárselas en el agua $[\ldots]$

- Yo agradezco tu buena intención, amigo Sancho - respondió don Quijote-; mas quiérote hacer sabidor de que todas estas cosas que hago no son de burlas, sino muy de veras; porque de otra manera sería contravenir a las órdenes de caballería, que nos mandan que no digamos mentira alguna, pena de relasos, y el hacer una cosa por otra lo mesmo es que mentir" $[2,261]$.

De igual modo, fingir que se ama a Dulcinea cuando en realidad se ve -y ni siquiera se ama ya - a Aldonza, "lo mesmo es que mentirn.

Si tras Dulcinea don Quijote ve a Aldonza Lorenzo ¿qué le impide ver los molinos tras los gigantes, o las ventas tras los castillos, o los rebaños tras los ejércitos? Hay una autoconsciencia tan grande en ese desvelamiento de sus artes de transmutación del mundo que no es posible pensar que él pueda seguir creyendo en sus propias criaturas. Y sin la fe en sus propias ideas su acción pierde el fundamento; si hubiera sido capaz de ver la realidad tal como era y no como se le presentaba a su mente perturbada, nunca hubiera ido contra "su rey y señor natural" libertando a los galeotes [I,22], ni hubiera atacado a los clérigos acompañantes de la dama vizcaina $[\mathrm{I}, 8]$ ni a los del cuerpo muerto $[\mathrm{I}, 19]$, pues hubiese sido tanto como ir contra la propia orden de caballería que le imponía la defensa de la religión y de la propiedad real.

1.2. Estas reflexiones no van encaminadas a poner en entredicho la cohesión interna del personaje de don Quijote; no es ése nuestro interés; sí lo es, sin embargo, subrayar en esta contradicción de don Quijote una característica que lo definirá en un estado más avanzado del relato: la autoconsciencia. Hasta este momento lo que lo definía era la voluntad de ser, el querer ser ${ }^{13}$; pues bien, en ese diálogo con Sancho ya se esboza la clave de su transformación posterior: el saber ser, bajo forma de consciencia del querer ser caballero andante. No pretendo decir con esto que Cervantes, en este punto de su narración, tuviera ya en la mente todos los desarrollos futuros de la ilustre pareja; ni tanto menos que este

13 ORTEga (op. cit., pp. 213 y ss.) ya veía en la voluntad de aventura de don Quijote la clave de sus acciones. A. CASTRO ("Los prólogos del Quijote», Revista de Filología Hispánica. 1941 [ahora en Hacia Cervantes. Madrid, Taurus, 1967, pp. 231 266 [pp. 249, 252]; y "La estructura del Quijote», Realidad, 5, II, 1947, pp. 145-70 [ahora en Hacia Cervantes, cit., pp. 267-291] [p. 267], distingue entre la voluntad proyectiva de don Quijote y la receptiva de Sancho. Según J. B. Avalle-ARCE (Nuevos deslindes cervantinos. Barcelona, Ariel, 1975, p. 32) la voluntad marca el inicio de la acción quijotesca y su final, la muerte, que es la abdicación de la voluntad de ser de don Quijote. En opinión de C. SEGRE ("Costruzioni rettilinee e costruzioni a spirale nel Don Chisciotten, en Le strutture e il tempo. Torino, Einaudi, 1974, pp. 183-219 [p. 199], esa misma voluntad de creer sería la que daría una nueva dimensión menos enajenada, si entra dentro de lo posible, de la locura de don Quijote. 
episodio pertenezca a un período de redacción posterior en que Cervantes ya hubiera asimilado la nueva evolución de sus personajes y decidiera volver atrás para darles ya unas pinceladas de sus nuevos colores constitutivos; pero sí quiero poner de relieve cómo, a la hora de diversificar al personaje de sí mismo, Cervantes escoge ya en la I Parte características que mostrarán toda su eficacia solamente en la II ${ }^{14}$.

Y nótese que no se habla aquí de un cambio de perspectiva en la visión de don Quijote, de una posible manifestación de multiperspectivismo defendido por L. Spitzer en sus ensayos ${ }^{15}$, ni de una realidad que cambia según las circunstancias, la realidad oscilante de Castro 16; el objeto observado es el mismo (Dulcinea), las circunstancias también (don Quijote y Sancho a coloquio), como también lo es el punto de vista (el de don Quijote). Se trata de una verdadera ruptura de la coherencia ideológica de don Quijote y del sistema de atributos que conforman su personalidad, y no de una evolución o un leve cambio en el sistema, como se podría pensar. Lo prueba el hecho de que a partir de ella don Quijote no sea consecuente con esa visión transformada, y que, contrariamente a lo que cabría esperar, don Quijote se reafirme en su primitivo estatuto caracterial. Escuchemos sus palabras en la disputa con Sancho acerca de si se ha de casar o no con Micomicona:

"Decid, socarrón de lengua viperina, y ¿quién pensáis que ha ganado este reino, y cortado la cabeza a este gigante, y héchoos a vos marqués (que todo esto doy ya por hecho y por cosa pasada en cosa juzgada), sino es el valor de Dulcinea, tomando a mi brazo por instrumento de sus hazañas? Ella pelea en mi, y vence en mí, y yo vivo y respiro en ella, y tengo vida y ser" $[I, 30,2,407]$.

El monolitismo, la solidez, la interconexión necesaria de todos los elementos del mundo de don Quijote nos resultan, ahora sí, familiares; reconocemos en estas palabras al don Quijote caballero andante. Para su acción es indispensable que exista Dulcinea; es el sustento de la misma; si no creyera en Dulcinea no creería en sus acciones, porque Dulcinea es el alfa y el omega de todos los valores que él defiende, la fuerza centrípeta que ordena sus hazañas

14 Con todo, convendrá puntualizar que ni siquiera entonces, cuando don Quijote ya haya tenido noticia de su existencia como personaje libresco, se comportará como si dominara claramente los mecanismos de su demencia; su curación final lo demuestra, pues no hubiera sido necesaria si él en cualquier momento podía tener ya esa misma proyección de sus actos.

is Como es sabido L. SPITZER («Perspectivismo lingüístico en el Quijote», en Lingüistica e historia literaria Madrid, Gredos, 1955, pp. 135-187) habla del multiperspectivismo como característica de la visión de la realidad de Cervantes cuando sobre un mismo hecho el narrador deja que se expresen diferentes personajes; no ofrece ningún ejemplo en que un mismo personaje cambie de punto de vista.

16 CASTRO, El pensamiento de Cervantes, cit., pp. 122 y ss. 
en serie única en torno a su persona y el elemento de unión entre la realidad y las ideas.

Por lo tanto, la doble visión antitética de Dulcinea no proviene, como pudiera parecer, de la manifestación por separado de los dos términos de la antítesis loco/cuerdo que define la personalidad de don Quijote. Los personajes que entran en contacto con don Quijote le reconocen una inteligencia y una lucidez envidiables, cuando la ejercita en discursos; cuando, por el contratio, trata de temas de la andante caballería da en la locura más completa; es loco en lo caballeresco y cuerdo en lo normal. Pero antes de manifestar su dicotomía caracterial ante los demás ha constituido esa dicotomía transformando la realidad y transformándose a sí mismo en función de ella. Dulcinea es uno de esos temas caballerescos y uno de los elementos fundadores de la vertiente enajenada de la antítesis. Para captar esa función primordial de Dulcinea que la aboca a una existencia unívoca en la esfera de la locura iremos a espiar el momento crucial en que don Quijote determina hacerse caballero andante:

"Y asentósele de tal modo en la imaginación que era verdad toda aquella máquina de aquellas sonadas soñadas invenciones que leía [los encantamientos, desafíos, amores, de los libros de caballerías], que para él no había otra historia más cierta en el mundo.» $[\mathrm{I}, 1,1,87]$

La primera fase de la locura quijotesca es la fe en los libros ${ }^{17}$, que le lleva a creer que la ficción es la realidad, que las palabras son los hechos, y los signos las cosas ${ }^{18}$ :

17 La presencia viva de los libros en el Quijote ha sido objeto de gran número de trabajos críticos. Entre los principales se cuentan los de M. DE RIQUER, «El Quijote y los libros», Papeles de Son Armadáns, núm. 160 (1969), pp. 5-24, y "Cervantes y la caballeresca", en AA.VV., Suma cervantina (editada por J. B. Avalle-Arce y E. C. Riley), London, Támesis, 1973, pp. 273-292. A. CASTRO («La palabra escrita y el Quijote», Asomante, 3, 1947 [ahora en Hacia Cervantes, cit., pp. 292-324]), por ejemplo, ve en la consideración de los libros como algo vivo el influjo de la tradición oriental. Para FUENTES (op. cit., p. 93) el Quijote es la primera novela moderna precisamente porque incluye en su propia estructura temática la crítica literaria y la autocrítica. Según L. SPITZER ("Sobre el significado de don Quijoten, en Estilo y estructura en la literatura española. Barcelona, Crítica, 1980, pp. 291-309) Cervantes se vale del perspectivismo en los puntos de vista para imponer el mensaje de su obra que no es otro que el de la crítica a la lectura de los libros de caballerías. Cfr. también J. Herrero, "La metáfora del libro en Cervantes", en AA.VV., Actas del séptimo Congreso de la AIH. Roma, Bulzoni, 1982, I, pp. 579-584; M. MONER, "La problemática del libro en el Quijote", Anthropos, 9899,1989, pp. 90-92. El cambio de la relación entre el ser y la representación del mundo inherente a la visión literaria origina la novela moderna, y eso no hubiera sido posible sin la desmitificación de la literatura tradicional que Cervantes realiza en el Quijote; son las ideas expuestas por J. RODRfGUez PUÉRTOLAS, en "Cervantes, Don Quijote y la novela moderna", Anthropos, 100, 1989, pp. 49-53.

${ }_{18}$ Cfr. M. FoucaUlt, Las palabras y las cosas. Madrid, Siglo XXI, 1981, pp. 53 57 [1.a ed. francesa 1966]. Para una discusión de las ideas de este ensayo vid. C. SAMONÄ, "Foucault e la follia di don Chisciotte», en AA.VV., Identità e metamorfosi del barocco ispanico, al cuidado de G. Calabrò. Napoli, Guida, 1987, pp. 149-157. 
"Decía él que el Cid Ruy Díaz había sido muy buen caballero; pero que no tenía que ver con el caballero de la Ardiente Espada" [ibidem].

Inmediatamente después decide hacerse caballero andante; y ésta es la segunda fase de su locura:

«En efecto, rematado ya su juicio, vino a dar en el más estraño pensamiento que jamás dio loco en el mundo, y fue que le pareció convenible y necesario, así para el aumento de su honra como para el servicio de su república, hacerse caballero andante» $[I, 1,1,89-90]$.

La voluntad de ser caballero andante resulta, pues, la primera manifestación de su locura; no hay en ella un mínimo de autoconsciencia, de cordura. Como tampoco la hay, a mi modo de ver, en el hecho de que no quiera probar por segunda vez su recompuesta celada tras que la deshiciera con la espada:

"La tornó a hacer de nuevo, poniéndole unas barras de hierro por de dentro, de tal manera, que él quedó satisfecho de su fortaleza $y$, sin querer hacer nueva experiencia della, la diputó y tuvo por celada finísima de encaje" $[I, 1,1,92]$.

La frase «sin querer hacer nueva experiencia della» expresa, según la opinión de algunos insignes estudiosos, la intencionalidad, la autoconsciencia de don Quijote, y, por consiguiente, su deseo de representar el papel de caballero andante ${ }^{19}$; un claro ejemplo de la primacía de la lucidez sobre la alucinación en el esquema

La palabra como elemento que metamorfosea la realidad en don Quijote y la importancia del acto de nombrar para él es una idea que ya encontramos en el ensayo de P. SALINAS, "El polvo y los nombres", en Ensayos de literatura hispánica. Madrid, Aguilar, 1961, pp. 127-142 [p. 132].

19 TORRENTE, op. cit., y VAN DOREN, op. cit., toman como punto de partida de sus lecturas del Quijote escenas en las que don Quijote parece mostrar la misma conciencia de las repercusiones de sus actos que en ésta; acepta sustancialmente esta interpretación L. A. Murillo ("La espada de don Quijote -Cervantes y la poesía heroica-", en AA.VV., Cervantes su obra y su mundo, dirección de $\mathrm{M}$. Criado de Val. Madrid, Edi-6, 1981, pp. 667-680 [p. 678]), para quien el hecho de que, por ejemplo, don Quijote no ponga nombre a su espada hay que interpretarlo como una prueba de que nunca dejó de ser un hidalgo y de que no se acostumbró a ser un caballero. MADARIAGA (op. cit., pp. 127-9) analiza concretamente el episodio de la celada por considerarlo emblemático del carácter de don Quijote y concluye diciendo que kaún en su locura [de don Quijote], no muere del todo la razón». No deja de ser curioso que en la misma escena un cervantista de excepción como B. CROCE (Poesia antica e moderna. Bari, Laterza, 1941, pp. 247-256 [pp. 251-2]) haya leído justamente lo contrario, es decir, un momento en que don Quijote se engaña a sí mismo. Así parece interpretarlo también L. CERNUDA ("Cervantes", Anthropos, suplementos 16, 1989, pp. 68-76 [p. 74]) que considera esta actitud de don Quijote como la máxima expresión de su locura. Como supremo acto de su voluntad, en cambio, la considera O. H. GREEN (España y la tradición occidental Madrid, Gredos, 1969, vol. I, pp. 222-243 [p. 233]). MARTINEZ BonaTI sintetiza las posiciones de Van Doren, Torrente y Madariaga en su estudio "El Quijote: Juego y significación*, Dispositio, vol. III, núm. 9, 1978, pp. 315-336 [p. 330]; según Martínez Bonati el incidente de la celada revela que la locura de don Quijote conjuga dos componentes 
caracterial de don Quijote. Ahora bien, si es la locura -y eso pienso que está fuera de discusión- la que le hace creer que el débil encaje de cartones, con el que en un primer momento completa el morrión, podrá resistir los golpes de su espada, habrá de ser la locura también la que le haga creer que ha resuelto el problema con el añadido de unas barras de hierro: por eso don Quijote no quiere volver a probar lo que ya considera «celada finísima de encaje» - y no es más que morrión mal compuesto-, porque queda "satisfecho de su fortaleza", y no porque tema volver a deshacerla. La innegable cercanía entre la voluntad y la consciencia, en este caso, resulta anulada por la explicitación de la causa de ese "no querer", que no es la consciencia sino la creencia de que la celada ya es inmejorable.

A pesar de que el nombre no se lo dé hasta unas páginas más adelante, éstos son los primeros actos de don Quijote, y no los últimos de Alonso Quijano, como nos confirma el sentido global del párrafo:

"Le pareció convenible y necesario hacerse caballero andante [...] y así se dio priesa a poner en efeto lo que deseaba. Y lo primero que hizo fue limpiar unas armas» $[I, 1,1,89-91]$

La tercera fase de su locura es precisamente ésta en que se procura los aperos propios de su nueva misión. Entre ellos están las armas, el caballo, y también un nombre y una alta dama de quien enamorarse "porque el caballero andante sin amores era árbol sin hojas y sin fruto y cuerpo sin alma" $[I, 1,1,96]$. Y así elige

a primera vista contradictorios: el querer ser, y por eso don Quijote se hace una nueva celada, y el querer fingir, por eso no la pone a prueba. Esta dicotomía constitutiva del carácter de don Quijote se aprecia, en opinión de Martínez Bonati, en más escenas, pero donde más claramente se puede ver es en la que él denomina "el incidente de la celada" y en el desclasamiento de Dulcinea a simple aldeana. Ambos episodios, para Martínez Bonati, son verdaderas incongruencias en la personalidad de don Quijote, que dejan de serlo si se acepta la explicación que él ofrece: de este modo, lo que parecía ofrecerse como un indicio de una concepción cervantina del personaje no muy en consonancia con su pretendido realismo - realismo que el propio Bonati ha puesto en tela de juicio en varios de sus trabajos (cfr. "Cervantes y las regiones de la imaginación", Dispositio, vol. 11, núm. 1, 1977, pp. 28-53, y «La unidad del Quijoten, en AA.VV., El "Quijote" de Cervantes, ed. de G. Halev, Taurus, Madrid, 1987, pp. 349-372 [p. 355]-, como una pista para comprender la probable constitución literaria y fragmentaria de don Quijote, vuelve a la sistematización unitaria sobre la que se basa precisamente el realismo de los personajes. Pero, no es éste el momento de abrir una discusión sobre el argumento, por lo que me limito a manifestar mi desacuerdo con el paralelo entre las dos escenas mencionadas que establece Bonati; en mi opinión no soportan la comparación porque en un caso, el de la celada, don Quijote actúa dentro de los límites de su locura, y en el otro demuestra una consciencia de la realidad incompatible con su locura y con su propio programa de acción. 
a Aldonza Lorenzo ${ }^{\circ}$, a sabiendas de que es la misma de la que anduvo enamorado tiempo atrás, y "a ésta le pareció ser bien darle título de señora de sus pesamientos" $[I, 1,1,97]$. En el momento mismo en que hace su elección transforma al objeto de la misma en su nueva identidad, sin que para él queden rastros de lo que fue antes. Es la misma operación que había realizado con el morrión que será celada y que realiza con Rocinante, el cual, pese a que "tenía más cuartos que un real y más tachas que el caballo de Gonela» [I,1,1,92], le parecía a don Quijote tal "que ni el Bucéfalo de Alejandro ni Babieca el del Cid con él se igualaban" $[I, 1,1,93]$.

En sus primeras acciones como caballero andante don Quijote convierte los objetos del mundo real en los signos del mundo ficticio en que vive; repara así los defectos de su constitución en caballero - título y misión a los que por pobre y viejo no tenía derecho a aspirar ${ }^{21}-$, valiéndose del elemento clave de sus futuras hazañas: la voluntad. A don Quijote al principio el verbo se le hizo carne: lo que sólo debía parecer fue, en la primera fase de su locura la ficción se le hizo realidad. Después, en la tercera fase, es al revés: lo que es le parece, la realidad se le hace ficticia; en la primera fase de su enajenación Alonso Quijano es sujeto paciente de la metamorfosis; durante la tercera don Quijote deviene sujeto agente de la misma; y entre ambas se produce la metamorfosis del propio Alonso Quijano en don Quijote por efecto de su propia fuerza de voluntad, con lo que su locura invierte los términos en

20 R. LAPESA ("Aldonza-Dulce-Dulcinea», en De la Edad Media a nuestros dias. Madrid, Gredos, 1967, pp. 212-218) estudia el origen de este nombre y sus connotaciones y les contrapone la musicalidad y ligereza de Dulcinea, apelativo que revela la matriz pastoril como una premonición de la última locura de don Quijote.

${ }_{21}$ Ralmundo Lulio (Libro del orden de caballería. Buenos Aires-México, EspasaCalpe Argentina, 1949, p. 51) especifica las causas del rechazo: «Si el escudero es demasiado viejo o debilitado en el cuerpo, tampoco es conveniente sea armado caballero: porque por ello se cometería injuria contra el orden de caballería, que exige combatientes fuertes por su honorw. Alfonso X en la Segunda Partida, Título XXI, Ley 12 "Cuáles no deben ser caballeros" (Las siete Partidas. Madrid, Publicaciones Españolas, 1961, tomo II, pp. 47-9), estipula que «no sea caballero hombre muy pobre si no le diere primeramente consejo el que lo hace por que pueda bien vivirw.

M. DE RIQuer («Don Quijote caballero por escarnion, Clavileño, núm. 41, 1956, pp. 47-50) aduce además otra razón por la que, siguiendo Las Partidas del Rey Sabio, don Quijote no hubiera podido ser considerado caballero andante, y es que había sido investido caballero por escarnio. Contra esta idea reacciona G. B. Palacín ("Sobre el acto de armar caballero a don Quijote», Hispanófila, 42, 1971, pp. 1-6) argumentando que la fe en el acto de investidura de don Quijote es suficiente para justificar el título. En esa misma creencia de don Quijote hace hincapié J. M. PEMÁN ( el capítulo III de la primera parte-", Boletín de la Real Academia Española. Tomo XXVII, 1947-1948, Madrid, pp. 7-19) para defender la idea de que no hay intención paródica de Las siete Partidas en esa investidura. 
que empezó a presentarse ${ }^{22}$ y el relato abandona la estructura pasiva por la activa. Don Quijote no niega lo que para él son las apariencias de las cosas; simplemente no las acepta y las convierte en esencia; no existe fractura posible entre el mundo literario, idealizado, de sus aventuras y el de la realidad que le rodea y precisamente porque no ve esa fractura se lanza a la acción ${ }^{23}$. Es cierto que todas sus acciones, en principio, proceden de un acto de voluntad; pero también lo es que ese acto de voluntad nace de su locura. Por eso no tiene sentido que sea capaz de reconocer en Dulcinea a Aldonza, y mucho menos que se percate de la operación a que la somete; completamente fuera de su persona queda ya la consciencia de haber trasformado el mundo en su propio interés; nada más alejado del platonismo de don Quijote ${ }^{24}$ que el criterio del interés para sus acciones.

22 El querer ser caballero andante, que la convicción de que lo leído era real le ha instalado en el magín, se vuelve el motor principal de su transformación del mundo. Sólo porque al ventero Juan Palomeque le falta este elemento no segundará a don Quijote, como le pronostica Dorotea; claro que la confusión del ventero nace de la ignorancia y la de don Quijote de la excesiva sabiduría; son hasta cierto punto antitéticas. Don Quijote es un empedernido lector que termina confundiendo los signos con las cosas mientras no se sale de su rol de sujeto paciente, mientras se queda en casa; cuando se echa al mundo en busca de aventuras, la operación se invierte y confunde las cosas con los signos. F. LÓPEZ ESTRADA ( La aventura frustrada. Don Quijote como caballero aventurero", Anales cervantinos, 3, 1953, pp. 161-214) se basa en esta búsqueda de aventuras para puntualizar que don Quijote no era un caballero andante sino un caballero aventurero, tipo de paladín que aún abundaba, además, en la España de aquel entonces. Un hecho que M. DE RIQUER (Caballeros andantes españoles. Madrid, Espasa-Calpe, 1967) documenta históricamente hasta principios del siglo anterior. M. MOLHO («Pourquoi/de quoi Don Quichotte est-il fou?", Bulletin Hispanique, LXXXX, 1988, pp. 147-154) subraya en el binomio locura/caballeria el elemento fundacional de esta novela que concluye, y no casualmente, cuando el protagonista renuncia a ambos elementos.

${ }_{23}$ FoucAulT, op. cit., dedica unas enjundiosas páginas al tratamiento de este aspecto de la personalidad de don Quijote; en ellas define así las acciones del hidalgo manchego: «Su aventura será un desciframiento del mundo; un recorrido minucioso para destacar, sobre toda la superficie de la tierra, las figuras que muestran que los libros dicen la verdad. La hazaña tiene que ser comprobada; no consiste en un triunfo real [...], sino en transformar la realidad en signo. En signo de que los signos del lenguaje se conforman con las cosas mismas. Don Quijote lee el mundo para demostrar los libros" [p. 54].

Don Quijote es loco porque confunde la realidad con la ficción, pero no porque lea en las cosas los signos, en las apariencias las esencias; la operación que le permite interpretar el mundo como la realización material de un sistema superior de significados, como la realización sintagmática de un paradigma, constituye el núcleo central de la visión medieval del mundo, lo que vendría a dar a su acción unos ribetes de anacronismo. Por estas características del mundo medieval Ju. M.Lotman ( Il problema del segno e del sistema segnico nella tipologia de la cultura russa prima del XX secolon, en Ju. M. LOTMAN y B. A. USPENSKIJ, Ricerche semiotiche. Torino, Einaudi, 1973, pp. 40-63 [p. 41] [he utilizado la versión italiana de la obra]) lo incluye dentro de los modelos sociales de tipo paradigmático.

${ }_{24}$ Cfr. E. MORENO BÁEZ, "Arquitectura del Quijoten, Revista de Filología Es. pañola, 32, 1948, pp. 269-285 [pp. 277-8]; y J. CAMÓN AZNAR, «Don Quijote en la teoría de los estilos", Revista de Filología Española, 32, 1984, pp. 429-465 [p. 434]. 
Las intervenciones de don Quijote, sus actos caballerescos, revelan el abismo entre lo que él considera apariencia y la esencia de las cosas. A hechos consumados su oído se abre a las palabras de Sancho, entra en diálogo con él, acepta que pueda haber algún atisbo de verdad en lo que su escudero le dice y le decía al ir a acometer la aventura; pero, antes de que ese abismo ocupe un espacio en su mente, ya su sabiduría del código caballeresco ha colmado el vacío de la decepción por la derrota; como no puede ser que tan alto representante de la Verdad y la Justicia haya podido ser menoscabado por su enemigo $-\mathrm{y}$ aquí la conciencia del valor ordaliaco de los actos del caballero se hace patentenecesariamente ha debido intervenir un elemento mágico, un encantador adversario, que le negara la victoria ${ }^{25}$. De este modo la apariencia - tan evidente e innegable como los golpes que el hidalgo acaba de recibir - torna a desaparecer bajo la pujanza de la esencia y todo vuelve a su sitio en el mundo de las ideas habitado por el caballero.

El querer ser de don Quijote convierte a las cosas en signos; el poder ser (el hacer) las devuelve a la realidad; y el saber ser ${ }^{26}$ las vuelve a la esencia. El círculo se ha reconstruido: el hacer de don Quijote se basa en su querer ser y éste en el saber ser que continuamente aparece reafirmado por su acción. El ser social de don Quijote, que con su nuevo proyecto de vida se centra en el hacer, en lo que demuestra a los otros que es con sus acciones, tiene como único fundamento su querer ser; pero en el momento en que sus actos están a punto de dar al traste con su imagen don Quijote echa mano de su saber ser ${ }^{27}$ y todo vuelve a su cauce.

Don Quijote tiene conciencia de su persona, pero es de signo muy diferente a la que venimos discutiendo aquí; es más una

${ }_{25}$ El papel de los encantadores en el relato de las aventuras de don Quijote ha merecido la atención de varios estudiosos entre los que se cuentan MADARIAGA, op. cit., pp. 131-2; H. HATZFELD, El Quijote como obra de arte del lenguaje. Madrid, Patronato del IV centenario del nacimiento de Cervantes, 1949, pp. 34-9; R. L. PREDMORE, "La función del encantamiento en el mundo del Quijoten, Anales cervantinos, V, 1955-56, pp. 63-78, y El mundo del Quijote. Madrid, Insula, 1958, pp. 55-76; Foucault, op. cit., p. 54; TORRENTE Ballester, op. cit., p. 150. Para R. GARAudy (La poesía vivida: Don Quijote, Córdoba, El Almendro, 1989, p. 29) los encantadores representan la alineación del capitalismo naciente contra la que don Quijote ya lucha.

${ }_{26}$ Estas tres categorías semánticas pertenecen al grupo de los enunciados modales, que según A. J. Greimas (Del senso. Milano, Bompiani, 1974, pp. 179-187 [Du sens, 1970]) explicitan las acciones que él llama actores.

27 Peculiaridad de las acciones quijotescas por la que, en opinión de CASTRO ( La estructura del Quijoten, cit., pp. 267-291), se descubre la profunda raigambre semítica de la concepción del mundo de Cervantes. La misma idea es mantenida por L. SPITZER, "Soy quien soy", Nueva Revista de Filología Hispánica, I, 1947, pp. 113-27. Con mucha convicción sostiene la misma idea L. RoDRíguEz («Don Miguel, judio de Cervantesw, en AA.VV., Cervantes su obra y su mundo, cit., pp. 197-200) y la acompaña de una propuesta extravagante: Cervantes nació en un pueblecito de la comarca de Sanabria. 
conciencia de su personaje que de su persona. Don Quijote en cada momento sabe qué debe a su modelo de caballero andante, sin percibir, en cambio, ninguna separación entre él y su modelo, entre Alonso Quijano y don Quijote; sabe que quiere imitar el ideal de caballero que él ve contenido en su propio nombre, pero no sabe - no puede saberlo- que está loco. Este don Quijote capaz de tener ante sus ojos la imagen real de Aldonza Lorenzo, sin dejar de invocar a Dulcinea a las primeras de cambio, no parece concordar muy bien con el equilibrio de atributos funcionales del personaje en que se han venido originando sus acciones ${ }^{2 *}$.

\section{CARTAS, PENITENCIAS Y PRINCESAS ALDEANAS}

2.1. Hemos calibrado el alcance de la incongruencia sometiéndola al foco de luz de la personalidad del protagonista; pero eso no nos ha aclarado sus causas. Intentaremos ahora percibirla en su contexto y relacionar este nuevo don Quijote desengañado y descreído con el que no recuerda que su amada no sabe leer ni escribir, por si eso nos aportara alguna luz. Por de pronto hay que señalar que don Quijote en I,30 - el capítulo anterior a su incongruencia respecto a la cultura de Dulcinea- vuelve a la visión idealizada de su dama, mientras que la visión materialista y desengañada de Aldonza/Dulcinea $[\mathbf{I}, 25]$ viene a renglón seguido de su frase sobre la posibilidad de que Dulcinea lea su carta. Las dos contradicciones del personaje parecen presentarse en paralelo, motivo más que suficiente para que volvamos a la Sierra en busca de nuevos indicios sobre estos comportamientos anómalos de don Quijote.

Y como primera medida tomaremos en consideración el episodio que más se aproxima a éste de la embajada [I,25] por su visión realista de Dulcinea: el de la relación sobre la entrega de la carta que Sancho hace a don Quijote de vuelta en Sierra Morena [I,31,2,417-423]. El idealismo de don Quijote ha de enfrentarse también en este caso con el materialismo de Sancho sobre la dualidad Aldonza/Dulcinea; a cada sugerencia de don Quijote sobre la situación idealizada en que Sancho pudo haber entregado la carta a Dulcinea corresponde su reducción al plano material de la existencia por parte de Sancho: a cada referencia literaria de don Quijote, Sancho le opone una vital; a los detalles de cultura alta y codificada de don Quijote corresponde uno de cultura baja,

28 Habida cuenta de la afinidad entre este don Quijote descreido y el Caballero Desamorado de Avellaneda, no parece inverosímil que el plagiario se inspirara en él para construir su personaje. 
popular y existencial de Sancho ${ }^{29}$. Y así Dulcinea ni besa la carta, ni le hace "alguna ceremonia digna de tal carta», ni la pone encima de la cabeza, sino que la pone sobre un costal de trigo: cuando Sancho la halla no está "ensartando perlas o bordando alguna empresa con oro de cañutillo», sino "ahechando dos hanegas de trigon; la solícita petición de noticias que el caballero se imagina se transforma con la relación de Sancho en la indiferencia más absoluta, la sublime altura del estado social de Dulcinea en altura física, el "tuho de tienda de quantero" en "olorcillo algo hombruno", y la joya de las albricias en "un pedazo de pan y queso".

Pero no es tan interesante para nuestro estudio la oposición de las dos visiones de Dulcinea/Aldonza, como su neutralización final gracias al diálogo entre don Quijote y Sancho. Don Quijote, a cambio de obtener indicios sobre el sentimiento de su amada, transige paulatinamente con la figura que el malévolo Sancho le va presentando; claro que no le cuesta mayor esfuerzo que el de retraducir la traducción de Sancho a su código cortesano. Don Quijote se sustituye a los encantadores de otras veces y devuelve la realidad a su esencia idealizada: los granos de trigo se transmutan en granos de perlas con el simple toque de las manos de Dulcinea, que luego obtienen pan candeal de un simple trigo rubión; su indiferencia por la carta se convierte, en palabras de don Quijote, en necesidad de aislamiento para «leerla despacio y recrearse con ella"; la altura física en grandeza de alma; el olorcillo hombruno en el propio olor de Sancho; y las albricias negadas en falta de joyas en aquel momento para darlas. Don Quijote se amolda a la visión de Sancho y sin salirse un punto de su mundo idealizado, acepta la analogía entre su idea de Dulcinea y la persona real de Aldonza. El paso siguiente sería el que ya ha dado en I,25, cuando, presionado por un Sancho que acaba de sonsacarle la identidad real de Dulcinea, rebaja a su alta princesa al rango de vulgar campesina. Así que en I,31 Sancho contrapone a la credulidad inerme de don Quijote su listeza, a la necia idealización de don Quijote su materialización astuta de Dulcinea. En I,25 don Quijote opone a la materialización astuta de Dulcinea por Sancho

29 El escudero invierte carnavalescamente la idealización de don Quijote: Sancho, al igual que los escuderos de los héroes caballerescos (lo dice E. URBiNA, "El enano artúrico en la génesis literaria de Sancho Panzaw, Actas del séptimo congreso de la AIH (ag. 1980). Roma, Bulzoni, 1982, pp. 1023-1030, y «Sancho Panza a nueva luz: ¿Tipo folklórico o personaje literario?», Anales Cervantinos, XX, 1982, pp. 93-101), subraya la extravagancia de la vertiente amorosa de la historia. Basándose en esto Urbina sostiene la derivación de Sancho del prototipo caballeresco, aunque recoja en sí las características del tonto/listo folklórico. El origen literario de Sancho, y más concretamente su procedencia del personaje Ribaldo, el escudero del caballero Cifar, ya había sido planteado por M. MENÉnDEz Pelayo (Origenes de la novela, tomo I -ed. de Sánchez Reyes, E.-, en Obras completas, tomo XIII -ed. de M. Artigas-. Madrid, CSIC, 1943, pp. 311 y ss.). Para el origen popular tradicional de Sancho vid. M. MolHo, "Raíz folklórica de Sancha Panza", en Cervantes: raices folklóricas. Madrid, Gredos, 1976, pp. 215-336. 
el discreto proceso de encumbramiento que subyace a su materialización idealizada de Dulcinea/Aldonza. Pero para vencer sobre Sancho don Quijote ha tenido que descubrir tanto su persona que se sale de la oposición loco/cuerdo y entra en una autoconciencia que no le es propia.

Las dos escenas tienen un esquema generativo idéntico: la visión antitética de Dulcinea/Aldonza que tienen amo y escudero, y la confrontación dialéctica de ambas visiones ${ }^{30}$; entre ellas hay además una continuidad temática, pero mientras en la escena que aparece como consecuencia de la otra - la relación mentirosa de I,31- se mantiene la antítesis, en la primera - la embajada de I,25- se resuelve con la afirmación final de Sancho - "digo que en todo tiene vuestra merced razón" $[1,25,2,276]$-, en la que sintetiza la conversión de don Quijote hacia su punto de vista. Una escena anterior en el relato [I,25] parece resolver una situación narrada en otra posterior [I,31]; recoge los mismos planteamientos de oposición entre los personajes de la otra y los desarrolla hasta establecer un nuevo equilibrio dialéctico. De este modo el relato ofrece un desarrollo de las dos visiones del mundo y su colisión sobre el personaje de Aldonza/Dulcinea, pero ha de sacrificar a la coherencia temática la cohesión del personaje de don Quijote. El paralelo de estructuras profundas nos lleva a proponer como explicación posible de las dos incongruencias de don Quijote y de la de Sancho lo que será nuestra hipótesis de trabajo: Cervantes escribió, en primer lugar, la escena de la relación mentirosa [I,31] y después reescribió, o simplemente retocó, con la interpolación de algún que otro párrafo, la de la embajada de Sancho [I,25]. Con el orden actual del relato las dos intervenciones de don Quijote en ambas escenas han de ser consideradas como otras tantas infracciones: la primera contra el sistema de atributos del personaje; la segunda contra la primera, pues no es creíble que don Quijote reconozca en un primer momento la baja extracción social de Dulcinea y poco después rechace una descripción en consonancia de Sancho. Pero si suponemos que Cervantes reescribió el diálogo entre don Quijote y Sancho de I,25, después de la vuelta de Sancho a Sierra Morena, la reacción de don Quijote de I,25 se presenta como un paso más en la diatriba sobre Aldonza/Dulcinea - aún presente en la mente del escritor-, con el que, además de aceptar las modificaciones en la imagen de la doncella propuestas por Sancho en I,31, trata de cerrar la discusión sobre el argumento recuperando su ascendiente sobre él.

30 Don Quijote mismo en la réplica en que reconoce que Dulcinea es Aldonza [I,25] explicita la antítesis: «mas para que veas cuán necio eres tú y cuán discreto soy yo.... [2,272] Lo que para don Quijote es necedad en Sancho se reduce a la operación derrocante que éste ha cumplido con Dulcinea y lo que es discreción en él los términos de cultura alta con que la define. 
De haber sido así, deberían haber quedado huellas en el capítulo $\mathrm{I}, 25$, tanto de las interpolaciones a que probablemente fue sometido como de su escritura posterior al I,31; intentaremos descubrirlas en un rápido sondeo.

2.2. Según Stagg "el capítulo I,25 se distingue de los demás de la I Parte no dedicados a una historia episódica por su extensión; habría que achacarla, según él, a la fusión de varios pasajes procedentes de los capítulos afectados por la remodelación del texto que él defiende. La estructura discontinua y fragmentaria de I,25, causada por la fusión mencionada, se puede observar en la brusquedad de conexión de algunas partes del diálogo entre caballero y escudero, la gratuidad de algunos temas y las incongruencias narrativas. Con objeto de facilitar las referencias a cada uno de los componentes doy a continuación un resumen de I,25 con sus partes sigladas: a) se abre el capítulo con el diálogo sobre la disputa que don Quijote acaba de tener con Cardenio acerca de la honestidad de la reina Madásima; aquí el narrador sigue un modelo que usa muy a menudo, el que prevé un comentario de los personajes del episodio o relación de hechos apenas narrados; después cambia repentinamente el rumbo de la charla; b) don Quijote informa a Sancho de su decisión de imitar a Amadís en la penitencia de Peña Pobre y de enviar una carta a Dulcinea; c) luego, en una de sus réplicas, don Quijote vuelve a dar un giro brusco a la plática $\mathrm{y}$, sin que venga mínimamente a cuento, interpela a Sancho sobre la suerte que corrió el yelmo de Mambrino después de su batalla con los galeotes, lo que da pie a una discusión en torno al yelmo/bacía; d) entretanto llegan amo y escudero al lugar de la penitencia; allí vuelven sobre el tema de la imitación de Amadís y la carta a Dulcinea; e) y eso hace que su centro de interés se deslice suavemente hacia la figura de Dulcinea; $f$ ) con la lectura de la carta, las volteretas de loco penitente de don Quijote y la despedida de Sancho concluye el capítulo.

Stagg señala una figura narrativa entre a) y b) que probablemente fue provocada, según él, por la transposición desde aquí hasta el capítulo I,11 del episodio pastoril de Grisóstomo y Marcela ${ }^{32}$. No es ésta la única falla que se puede apreciar entre los vaivenes del diálogo; por encima de todas descuella la referencia al yelmo de Mambrino por su gratuidad; en la síntesis por puntos de más arriba se aprecia su cualidad de inciso sin ninguna atinencia al contexto; se halla entre los puntos b) y d), interrumpiendo su continuidad temática y lógica -don Quijote pasa de la idea de imitar a Amadís y escribir a Dulcinea, b), a su realización práctica, d)- L Lo confirmaría también, de forma indirecta, su incon-

31 StagG, "Cervantes revisa su novela (Don Quijote, I Parte)», cit., p. 21.

32 Es la idea de fondo de su artículo "Cervantes revisa su novela (Don Quijote, I Parte)», cit. 
gruencia con la última alusión al mismo utensilio, tres capítulos atrás, cuando sirvió de arma ofensiva al estudiante que arremetió al caído don Quijote

"y le quitó la bacía de la cabeza, y diole con ella tres o cuatro golpes en las espaldas y otros tantos en la tierra, con que la hizo pedazos" $[\mathrm{I}, 22,1,192]$ :

aquí, sin embargo, los dos personajes hablan de ella como si no hubiera sido destruida, sino solamente deformada:

"La bacía yo la llevo en el costal, toda abollada" [I,25,2,255].

La restauración de la bacía, aunque imperfecta, le devuelve todas las posibilidades funcionales que la convertirán más tarde en el objeto de la discordia en la venta de Palomeque. Probablemente Cervantes, a la hora de redactar la contienda de la venta, se dio cuenta de que no podía basar todo un episodio sobre un objeto destruido previamente, y se lo hace recuperar a don Quijote y Sancho en su charla, con una especie de prolepsis ${ }^{33}$, que anticipa ya en los términos y las posiciones defendidas la discusión de la venta de Palomeque. Escuchemos a don Quijote:

«Sancho, ¿traes bien guardado el yelmo de Mambrino, que ya vi que le alzaste del suelo cuando aquel desagradecido le quiso hacer pedazos? Pero no pudo" [I,25,2,254].

Es clara la alusión de las palabras con que el narrador, en la desigual lid con los galeotes, despachaba para chatarra el yelmo de Mambrino. Parece obvio que el narrador intenta desautorizar la otra intervención, si bien no deja de ser curioso que lo haga recurriendo al diálogo entre don Quijote y Sancho en I,25 y no corrigiendo directamente el episodio de los galeotes. Sobre la causa escoja el capítulo I,25 para el inciso de la bacía recompuesta no habrá que divagar mucho si aceptamos que es un capítulo hecho de los restos de otros, en el que un fragmento más no había de desentonar. Más difícil será explicar por qué no cambia los términos de la descripción en el episodio de los galeotes, ya que simplemente de eso se habría tratado ${ }^{34}$. Claro que bien mirado

33 Prolepsis o anticipación denomina G. GenETTE (Figure III. Torino, Einaudi, 1976, pp. 115-127 [Figures III, 1972]) a la alusión premonitoria de hechos futuros del relato.

${ }^{34}$ El respeto por el texto escrito y su inmutabilidad podría estar motivado aquí por cuestiones editoriales; no sería descabellado plantear una temprana difusión de la I Parte del Quijote, en forma reducida, sin la inclusión de los episodios intercalados del final. Podría haber sido una fase intermedia en la redacción de la obra, situada entre la probable novela corta del principio y la versión definitiva, que incluso habría llegado a las prensas. Y ipor qué no creer que sea esa hipotética segunda versión impresa a la que se refieren los diversos 
se puede vislumbrar en la renuncia a hacerlo una peculiaridad de la obra cervantina, la de ser una obra en devenir, que se hace desarrollando sugerencias de acción que ella misma ha esbozado anteriormente, que crece apoyándose en su propia estructura ${ }^{35}$; es lo que confiere ese aspecto de relato improvisado, que para algunos es apertura a la imprevisibiliad de la vida ${ }^{36}$ y para otros la clave de su realismo ${ }^{37}$.

En el discurso sobre el yelmo/bacía Sancho asegura que lo lleva en su costal, y éste se supone que va en la albarda de su burro; da a su burro por presente, igual que poco antes, en el punto a), había hecho don Quijote ("entremétete en espolear a tu asno" $[1,25,2,248])$. No obstante, pocas páginas más adelante, en el punto d), cuando don Quijote y Sancho vuelven a tratar de la imitación de Amadís (p. 260), Sancho lo da por ausente («bien haya quien nos quitó del trabajo de desanalbardar al rucio»), por lo que es fácil deducir que entre.el punto c) y el punto d) debía ir situado, en la primera redacción del Quijote, el episodio del robo del burro ${ }^{38}$; de ese modo no habría contradicción entre las dos alusiones al asno, que figurarían más alejadas textualmente, e incluso temporalmente a causa de la inevitable intercalación de la noche en que se produjo el hurto, según testimonio de Sancho ("tengo tal la cabeza del llanto que anoche hice por el rucio, que no estoy para meterme en nuevos lloros» [281]). Resulta así evidente

testimonios que atestiguan una difusión de la obra anterior a 1605? Cfr. J. OLIVER Asf́n, "El Quijote de 1604», Boletín de la Real Academia Española. XXVIII, 1948, pp. 89-126.

35 Este tipo de fenómenos es el que lleva a decir a V. SkLovsKI (Teoría della prosa. Torino, Einaudi, 1976, p. 132 [O teorii prozv, 1925]) que Cervantes usa una trama errante que le permite corregir los errores sobre la marcha.

${ }^{36}$ G. LUKÁcs (Teoría del romanzo. Roma, Newton Compton, 1975, pp. 158-9 [Die Theorie des Romans. 1920]) considera que la gran aportación del Quijote a la historia de la novela es la superación de la atemporalidad mítica de los libros de caballerías para centrar la trama en el devenir del tiempo de la vida (el planteamiento de Lukács permea el ensayo de J. R. RESINA, "La irrelevancia de la vida cotidiana en el Quijotex, Anthropos, 100, 1989, pp. 33-39). C. DE Coollis (Cervantes reazionario. Firenze, Sansoni, 1947, pp. 86-7) atribuye a la novela de Cervantes un delicioso desorden y una deliciosa frondosidad imitados de la naturaleza. Cfr. también CASTRO, "La palabra escrita y el Quijote», cit., p. 316. R. L. PREDMORE («El problema de la realidad en el Quijoten, Nueva Revista de Filología Hispánica, VII, 1953, pp. 489-498) asegura que Cervantes se interesa más por el hombre vivo que por la realidad objetiva. En opinión de F. Ayala (Cervantes y Quevedo. Barcelona, Seix Barral, 1974, pp. 135-6) las formas fluctuantes del género que Cervantes inventa -la novela moderna - son la expresión necesaria del reflejo de la vida.

37 Según M. Menéndez Pelayo («Cultura literaria de Miguel de Cervantes y elaboración del Quijotew en Estudios y discursos de crítica histórica y literaria, tomo I, pp. 255-420 [ed. de E. Sánchez Reyes], en Obras completas, volumen VI, cit., p. 315), Cervantes releva los casos de la vida familiar a la dignidad de la epopeyan.

${ }_{38}$ En la segunda edición de Juan de la Cuesta de 1605, que es la que en este punto sigue Rodríguez Marín y tantos otros editores, como el lector sin duda recuerda se sitúa el episodio del hurto al principio del cap. 1,23, es decir, al poco de haberse adentrado don Quijote y Sancho en Sierra Morena. 
lo que ya proponía antes, o sea que la conexión entre los puntos c) y d) -el del yelmo el de la imitación de Amadís- es fruto de una reelaboración del capítulo.

El paso entre d) y e) muestra también señales inequívocas de una remodelación. La conexión entre el diálogo sobre la penitencia y la carta y la conversación sobre Dulcinea parece, en efecto, algo forzada. El tema de la carta vuelve al diálogo entre don Quijote y Sancho después de que don Quijote elija el lugar de su penitencia: don Quijote pone en práctica la determinación de comunicar sus sufrimientos a su señora, pero entonces surge el problema de hallar recado para escribir en aquellas soledades, problema que en seguida soluciona don Quijote echando mano del librillo de memorias que acaba de encontrar en la maleta perdida por Cardenio. Sancho se encargará después de hacer trasladar la carta en papel, siempre que su amo satisfaga una objeción importante:

"-Pues ¿qué se ha de hacer de la firma? -dijo Sancho.

- Nunca las cartas de Amadís se firman - respondió don Quijote.

-Está bien - respondió Sancho-; pero la libranza forzosamente se ha de firmar, y ésa si se traslada, dirán que la firma es falsa, y quedáreme sin pollinos.

- La libranza irá en el mesmo librillo firmada; que en viéndola mi sobrina no pondrá dificultad en cumplilla. Y en lo que toca a la carta de amores, pondrás por firma: "Vuestro hasta la muerte, el Caballero de la Triste Figura". Y hará poco al caso que vaya de mano ajena, porque, a lo que yo me sé acordar. Dulcinea no sabe escribir ni leer, y en toda su vida ha visto letra mía ni carta mía» $[\mathbf{I}, 25,2,267]$.

En el espacio de pocas frases don Quijote resta importancia a la firma dos veces, con motivaciones diferentes y contradictorias; en la primera ocasión renuncia a poner su firma en la misiva por seguir el uso de los caballeros andantes; en la segunda porque Dulcinea, que no sabe leer y nunca recibió una carta de él, no sabría reconocerla. La segunda motivación es completamente ignorada por la primera -que parece incluso oponérsele abiertamente-, a pesar de que una información de ese tipo debía obrar en conocimiento de don Quijote cuando la formula.

Sancho en su pregunta se preocupa por la autenticidad de los dos escritos y si transige con la carta, después de que don Quijote le garantice que los caballeros andantes no las firman, no está dispuesto a hacerlo con la libranza, en la que personalmente le va mucho más. Sancho, con su objeción, anticipa los posibles reparos de Dulcinea ante una copia sin firma de la carta, porque considera éste el único detalle por el que Dulcinea podría cerciorarse de la falsedad del escrito, una vez resuelto el problema de la dignidad deseable en la transcripción con la buena letra de un maestro o un sacristán, pero no con la de un escribano «que hacen letra procesada [y] no la entenderá Satanás» [I,25,2,266]. Pero, ¿para qué tanta preocupación si la carta había de serle leída a la analfa- 
beta Aldonza Lorenzo por otra persona? La única respuesta posible es que don Quijote no tiene en la mente a la vulgar aldeana de la segunda motivación, sino a la alta princesa Dulcinea del Toboso; y no la tiene porque probablemente la segunda motivación ha sido interpolada aquí después de que el episodio ya hubiese sido redactado. De ahí que en ella don Quijote, por ejemplo, caiga en el error de decirle a Sancho cómo ha de siglar la copia, siendo así que ese pormenor ya debía figurar en el original, como efectivamente figura en su reproducción de la página 278. La interpolación llegaría hasta el momento en que Sancho pone punto final a la diatriba y solicita con urgencia la carta $[\mathrm{I}, 25,2,276]$, cosa que, por lo demás, ya había hecho, pero que ahora se ve obligado a repetir justamente a causa de la intercalación; que es lo que también sucede con su negativa a ver las sandeces de don Quijote [I,25,2,263 y 280].

Es de suponer que Cervantes se sirviera de la cuestión de la autenticidad de la misiva para conectar la interpolación de la disputa sobre Dulcinea a la discusión sobre la penitencia y la carta, y que al hacerlo no reparara en las contradicciones en que incurría reiterando una motivación que no respetaba el tono y el contenido del discurso anterior y que es a todas luces innecesaria. Con todo, habrá que decir que alcanza plenamente su objetivo, pues la discusión resulta perfectamente integrada en el contexto de toda la conversación.

Aludía más arriba a la posibilidad de hallar en este episodio intercalado las pruebas de su escritura posterior al capítulo I,31; creo haberlas encontrado en dos tipos de fenómenos diferentes: el uno es una clara incoherencia de don Quijote, y el otro dos formas de paralelismo discursivo, dos ecos, entre una intervención de Sancho en I,25 y otra de don Quijote en I,31 y entre unas palabras de Sancho en I,25 y una escena imaginada por él en I,31. Empecemos por la exposición de los indicios para terminar por las pruebas.

2.3. Sancho prevé una entrevista agitada con una Dulcinea reacia a conceder a don Quijote la evidencia de su amor, pero él ablandará su ánimo cruel y se precipitará a dar la buena nueva a su penitente señor:

"Volveré por los aires como brujo, y sacaré a vuestra merced deste purgatorio» $[1,25,2,266]$.

A la vuelta, después de la relación mentirosa, se asombra don Quijote de la celeridad en el retorno de su buen escudero:

"¿Sabes de qué estoy maravillado. Sancho? De que me parece que fuiste y veniste por los aires [...]; por lo cual me doy a entender que 
aquel sabio nigromante que tiene cuenta con mis cosas [...] te debió de ayudar a caminar» $[1,31,2,423]$.

Don Quijote y Sancho usan las mismas palabras para encarecer la rapidez del viaje de Sancho; los dos hablan de un desplazamiento aéreo y los dos lo asocian a una intervención mágica. Puede ser que sea una simple coincidencia de fórmula expresiva, pero también puede ser que sea un eco, un paralelismo involuntario; más allá de la duda es claro que la recurrencia discursiva relaciona las dos escenas, ya unidas en sus significados por una relación de causalidad, a nivel de los significantes.

Sancho en su encomio al revés de Dulcinea, antes de que don Quijote le replique, imagina una escena de pleitesía de un caballero a Dulcinea, en la que ya está en germen la relación falsa de la embajada:

"Pero bien considerado, ¿qué se le ha de dar a la señora Aldonza Lorenzo, digo, a la señora Dulcinea del Toboso, de que se le vayan a hincar de rodillas delante della los vencidos que vuestra merced le envía y ha de enviar? porque podría ser que al tiemnpo que ellos llegasen estuviese ella rastrillando lino, o trillando en las eras, y ellos se corriesen de verla, y ella se riese y enfadase del presente» $[I, 25,2,272]$.

La narración del diálogo entre Sancho y Dulcinea, como se recordará, presenta cruelmente una Aldonza atareada en las faenas del campo que no se ríe del presente, pero sí del nombre de don Quijote. El paralelo entre las palabras de Sancho y el supuesto recibimiento de Dulcinea no parece que se pueda interpretar como una coincidencia, o como un eco involuntario del discurso; es una forma de recurrencia, un eco, no hay duda; pero parece evidente que es un nexo cargado de significado relacional: las frases de Sancho en I,25 condensan la escena de la embajada inventada.

Estos dos paralelismos, ecos, o como los queramos llamar, podemos verlos como una especie de guiño del narrador al lector, como una anticipación cómplice de la escena futura, o bien como indicios de que Cervantes reelaboró el capítulo I,25 después de redactar el capítulo I,31, y que al hacerlo adelantó parte de la materia narrada en éste a aquél bajo forma de alusiones. Quizás la exposición del otro indicio del retoque resuelva el dilema en favor de la segunda hipótesis.

El indicio con probable valor de prueba se esconde, como ya se ha dicho, tras una especie de incongruencia de don Quijote. En su réplica al Sancho que demuestra conocer bien a Aldonza, el caballero alude a la inteligencia de su escudero:

"Ya te tengo dicho antes de agora muchas veces, Sancho - dijo don Quijote-, que eres muy grande hablador y que, aunque de ingenio boto, muchas veces despuntas de agudo» $[1,25,2,272]$. 
Pero se da el caso de que hasta entonces nunca antes don Quijote le ha reconocido a Sancho su astucia o su inteligencia, ni por su parte Sancho ha dado notables muestras de ellas; sí le ha tachado don Quijote de parlanchín tras los palos por su insolente remedo del habla caballeresca en la aventura de los batanes; dice don Quijote en esa ocasión:

"Jamás he hallado que ningún escudero hablase tanto con su señor como tú con el tuyo" $[1,20,2,119]$;

pero ni entonces ni después se pone a sopesar las dotes intelectuales de su escudero. Hemos de trasladarnos al final del relato de la misión de Sancho [I,31] para hallar a un don Quijote tan complacido con su escudero que hasta lo toma por consejero:

«Dígote, Sancho [...] que estarás en lo cierto, y que habré de tomar tu consejon $[\mathrm{I}, 31,2,427]$;

y cuando Sancho compara el amor de su amo por Dulcinea con el amor por Dios don Quijote exclama:

«iVálate el diablo por villano [...] y qué de discreciones dices a las veces! No parece sino que has estudiadon $[1,31,2,429]$.

Estos son los únicos cumplidos de don Quijote a su escudero que podrían justificar la alusión de más arriba ("ya te tengo dicho antes de agora muchas veces [...] que despuntas de agudo") ${ }^{39}$. Bien pudiera ser que en la mente de Cervantes estuvieran aún frescas aquellas palabras de I,31, y las que describen un retorno aéreo de Sancho ayudado por un encantador y también, con ellas, la carcajada irreverente de la Dulcinea sanchesca, cuando escribió éstas de la réplica de don Quijote en I,25, y las de Sancho sobre su fulmíneo regreso y la escena de pleitesía. El paralelo entre los dos episodios, sus ecos y sus recurrencias discursivas, es demasiado grande para no ver en ello la señal de una redacción casi simultánea; por lo que respecta a cuál de los dos se escribió antes, creo que las alusiones a la agudeza de Sancho son concluyentes para establecer una reelaboración de I,25 posterior a la escritura de I,31.

39 Sancho, a la vuelta de su embajada [I,31], actúa efectivamente en la discusión con su amo con una astucia y una agudeza de las que no había hecho gala hasta entonces; la prontitud con la que, sin haberlo vivido, opone un elemento grotesco al idealizado de su señor, sería suficiente para negar los rasgos del tonto folklórico que pudiera tener antes y reafirmar los del listo. Y precisamente a esas dos cualidades básicas de Sancho, el tonto/listo, se refiere don Quijote en la primera de las dos escenas al empezar la intervención en la que invertirá los términos de la oposición: otorga la agudeza de Sancho y la niega inmediatamente contraponiéndola a su propia discreción. Don Quijote desbanca a Sancho de su listeza y se sitúa él en ella para cerrar la disputa, a costa incluso de desmentir la existencia de Dulcinea y de traspasar las fronteras caracteriales y funcionales de su personaje. 
Si Cervantes escribió la partida de Sancho hacia el Toboso después de su llegada de allá, o si —como parece más probableretocó la partida después de redactar la llegada, es bastante lógico que teniendo que interpolar los nuevos párrafos en su contexto no distinguiese muy bien entre sucesos ocurridos hasta aquel punto y sucesos posteriores, e hiciera que sus personajes se refirieran a afirmaciones aún no hechas (como la de la astucia de Sancho), y que asimilaran informaciones aún no transmitidas (como la del analfabetismo de Dulcinea).

Entre las dos escenas hay una relación de presuposición lógica; la existencia de la una implica la de la otra y viceversa ${ }^{40}$; si don Quijote manda la carta Sancho ha de contar que la entregó, aunque sea mentira. La precedencia cronológica de una sobre otra obligaría a que en la que aparece en segundo lugar en el relato se recogieran las evoluciones de los personajes y de su relación, que los personajes asimilaran una serie de atributos o de informaciones sobre el mundo que se dan como existentes en la primera; es decir, obligaría a que don Quijote a la vuelta de Sancho no le preguntara si Dulcinea leyó la carta, ya que sabe que no lo podía hacer, a que no siguiera idealizando a su dama ante Sancho como si éste no hubiera sido informado por él ya en el momento en que lo manda como emisario de que todo es una simulación de don Quijote; Sancho, por su parte debería contraponerse a su amo cuando sigue tratando a Dulcinea como si realmente existiera y no fuera un fantasma de su imaginación, y no debería admitir a la vuelta de su misión que no conoce y nunca conoció a Aldonza, puesto que antes ha demostrado lo contrario.

Pero, en éste como en otros casos de descuido cervantino en la segunda situación no se asimila lo ya ocurrido, la consecuencialidad de las acciones pasa en segundo plano ante la preponderancia del diálogo entre hidalgo y escudero ${ }^{41}$. La incongruencia de sus respectivas informaciones sobre el objeto de la discusión en cada

40 Ambas serían catalogadas por R. BARTHES («Introducción al análisis estructural de los relatos», en AA.VV., Análisis estructural del relato. Puebla, Premiá, 1985 , pp. $7-38$ [p. 15]) como funciones cardinales, porque abren o cierran una alternativa consecuente para la continuación de la historia».

${ }_{41}$ Al perder la relación de consecuencialidad, los dos episodios se colocan en una simultaneidad temporal que abre las puertas a una nueva lectura, en la que establece un nuevo orden de sucesión de episodios. Puede perfectamente esta nueva lectura adoptar el criterio de acumulación de nuevos aspectos de la personalidad de los personajes como indicio de una escritura posterior de la escena que más novedades aporta respecto de su gemela. En este sentido el episodio de la redacción de la carta, tal como ahora está narrado, atribuye a don Quijote una cualidad añadida que contrasta con su personalidad, como creo haber demostrado más arriba; la autoconciencia de estar transformando el mundo según los ideales caballerescos contenida en la aceptación de la presencia de Aldonza en el fantasma de Dulcinea no tiene raíz alguna en el contexto narrativo anterior; sí la tendría, sin embargo, en la escena de la vuelta de Sancho, donde, como ha quedado dicho, 
uno de los episodios (don Quijote primero sabe y luego ya no que Dulcinea sabe leer: Sancho primero conoce y luego no a Dulcinea) cancela la continuidad lógica que se pudiera haber establecido. Sin embargo, la contraposición entre don Quijote y Sancho se refuerza y se enriquece de nuevos matices, aunque procedentes de sendas infracciones al equilibrio de atributos que albergaban ambos personajes. El narrador descuida la construcción del sintagma narrativo y satura de significados la oposición profunda entre el loco/cuerdo y el tonto/listo; margina la coherencia sintagmática en favor de una reemergencia constante en la estructura de superficie de elementos de la estructura profunda; antepone al devenir de los personajes su esencia, a sus acciones sus palabras, a su crecimiento su enriquecimiento ${ }^{42}$. Las incongruencias narrativas de Cervantes vienen así a corroborar algo que quizás ya otros elementos narrativos podían sospechar, es decir, que la esencia de la novela no está en la concatenación de las acciones de los personajes y por tanto tampoco en su crecimiento, sino en su capacidad proteica de transformación en las diferentes situaciones según se lo requiera la coherencia del momento y no según se lo imponga la coherencia de la sucesión de momentos. En principio, se podría pensar que estas alteraciones comportamentales desintegran la línea argumental del relato, pero, en un segundo momento, uno se puede percatar de que precisamente sobre esa reemergencia de los atributos de cada uno de los personajes, y por consiguiente de sus respectivas interpretaciones de la realidad circundante, se asienta la unidad de la trama y el dialogismo de la novela; sin estas alteraciones, sin las incongruencias de don Quijote y Sancho, tal vez no hubiéramos podido apreciar tan claramente las visiones encontradas del mundo de ambos, y en consecuencia del dinamismo de la estructura dialéctica ${ }^{43}$ del Quijote, fundamento y modelo de la novela moderna.

don Quijote ha de transigir con la visión material de la realidad propia de su escudero para poder arrancarle alguna intormación sobre su dama: basta con quitar la reintegración idealista de don Quijote a cada proyección materialista de Sancho para imaginar la admisión por parte del caballero de la mutación que ha llevado a cabo en la persona de Aldonza. Palabras de tan desengañado acento como «por [para] lo que yo quiero a Dulcinea del Toboso, tanto vale como la más alta princesa de la tierra" [2,273], sólo son posibles en boca de don Quijote después de la irreverencia de su escudero.

42 Esto es también lo que me hace restar importancia a los descuidos y considerar la exccisivat atención normativa del crítico por ellos como una suerte de pedantería de doclo in funciones de inquisidor.

43 Estas son las características por las que M. BACHTin (Teoría y estética de la novela. Madrid, Taurus, 1989, pp. 225-228) define al Quijote como la primera expresión conjunta de los componentes primordiales de la novela moderna. Cfr. también F. LÁZARO CARRETER, "La prosa del Quijote», en AA.VV., Lecciones cervantinas. Zaragoza, Caja de Ahorros, s. a., pp. 113-130; H. WEICH, «Narración polifónica: el Quijote y sus seguidores franceses (siglos XVII y XVIII, Anthropos, 98-99, 1989, pp. 107-112; I. M. ZavalA, "Cervantes y la palabra cercada", Anthropos, 100, 1989 , pp. 39-43. 
Y todo esto sin que suponga tal operación de continua referencia al modelo narrativo subyacente una modificación de las relaciones entre don Quijote y Sancho ni de sus respectivas posiciones respecto del mundo; como tampoco modifica el estatuto de los personajes; en nada cambia su condición; lo dicho al principio se repite pero en situaciones diferentes.

JosÉ MANUEl MARTíN MORÁN Universidad de Torino 